\title{
SISTEM PENDUKUNG KEPUTUSAN UNTUK MENENTUKAN PEMILIHAN SUPLIER PEMBELIAN OBAT-OBATAN TERBAIK DENGAN MENGGUNAKAN METODE FUZZY TSUKAMOTO PADA APOTEK GLOBAL MARTUBUNG
}

\author{
Ahmad Fitri Boy, Nurcahyo Budi Nugroho, Purwadi \\ Program Studi Sistem Informasi, STMIK Triguna Dharma \\ JI. A.H Nasution No.73 Medan, Sumatera Utara, 20142
}

\begin{abstract}
Abstrak
Pada apotek ini belum pernah melakukan pemilihan supplier terbaik menggunakan metode fuzzy tsukamoto ataupun metode lain, untuk itu penelitian ini dilakukan untuk membantu pihak apotek dalam memilih supplier terbaik. Supplier merupakan suatu perusahaan atau individu yang menyediakan sumber daya yang dibutuhkan oleh perusahaan dan para pesaing yang bertujuan untuk memproduksi barang dan jasa tertentu. Dalam menilai Supplier ada beberapa hal diperlukan berbagai kriteria yang bisa menggambarkan kinerja supplier secara keseluruhan yang menambah nilai saat ini (current value) maupun masa yang akan datang (future value). Sistem pendukung keputusan merupakan suatu sistem yang dirancang yang digunakan untuk mendukung pengambilan keputusan dalam suatu organisasi, intansi maupun perusahaan. Fuzzy Tsukamoto merupakan metode pengambilan keputusan yang mempunyai tingkat akurasi penilaian yang baik sehingga cocok digunakan sebagai metode dalam pengambilan keputusan. Hasil yang diperoleh dari sistem pendukung keputusan ini menunjukkan bahwa kemajuan ilmu pengetahuan dan teknologi dapat membantu instansi maupun perusahaan dalam menentukan pilihan yang tepat sesuai dengan pertimbangan dan perhitungan yang tepat. Sistem pendukung keputusan ini dapat memberikan solusi atau penyelesaian terhadap permasalahan pemilihan supplier terbaik dengan menggunakan metode fuzzy tsukamoto yang ada pada Apotek Global Martubung.
\end{abstract}

Kata kunci : Pemilihan Supplier, Sistem Pendukung Keputusan, Metode Fuzzy Tsukamoto

\begin{abstract}
This pharmacy has never made the selection of the best supplier using the Tsukamoto fuzzy method or other methods, so this research was conducted to help the pharmacy in choosing the best supplier. A supplier is a company or individual that provides the resources needed by the company and its competitors for the purpose of producing certain goods and services. In assessing suppliers, there are a number of things needed a variety of criteria that can describe the overall supplier performance that adds value to the current (current value) and the future (future value). A decision support system is a system designed to support decision making in an organization, agency or company. Fuzzy Tsukamoto is a decision-making method that has a good level of assessment accuracy so it is suitable for use as a method of decision making. The results obtained from this decision support system indicate that advances in science and technology can assist agencies and companies in making the right choice according to the right considerations and calculations. This decision support system can provide a solution or solution to the problem of selecting the best supplier by using the Tsukamoto fuzzy method available at the Global Martubung Pharmacy.
\end{abstract}

Keywords : Supplier Selection, Decision Support System, Fuzzy Tsukamoto Method

\section{PENDAHULUAN}


Salah satu kegiatan yang ada di apotek adalah transaksi penjualan obat-obatan kepada pelanggan dan transaksi pembelian obat dari supplier. Pemenuhan kebutuhan persediaan obat dilakukan dengan pemesanan ke berbagai supplier. Tidak semua supplier memenuhi kriteria yang ditetapkan apotek, maka harus dilakukan seleksi dan menuntut bagian pembelian untuk memilih Supllier yang tepat. Segala macam kegiatan manusia saat ini dapat dikerjakan dengan cepat dan mudah menggunakan Komputer.Sistem Pendukung Keputusan adalah salah satu bagian dari Sistem Informasi yang berguna untuk meningkatkan efektivitas pengambilan keputusan yang bertujuan untuk menyediakan Informasi, dapat membimbing, memberikan prediksi, mendukung analisis data, pemodelan keputusan, berorientasi pada perencanaan masa mendatang serta mengarahkan kepada pengguna Informasi agar dapat melakukan pengambilan keputusan dengan lebih baik.

Dari pembahasan diharapkan perangkat lunak yang dirancang dapat membantu pengguna untuk mengetahui pemilihan Supplier Obat. Berdasarkan Deskripsi masalah diatas maka di angkat Judul "Sistem Pendukung Keputusan Untuk Menentukan Supplier Pembelian Obat-Obatan Terbaik Dengan Menggunakan Metode Fuzzy Tsukamoto Pada Apotek Global Martubung ".

\section{METODE PENELITIAN}

Dalam melakukan penelitian tentu harus menggunakan beberapa metode penelitian, agar hasil dari penelitian sesuai dengan apa yang diharapkan, adapun metode yang digunakan dalam penelitian ini adalah:

1. Data Collecting (Teknik pengumpulan data)

Adapun beberapa teknik yang digunakan dalam pengumpulan data dari penelitian, yaitu:

a. Observasi (Peninjauan secara langsung)

Observasi adalah pengumpulan data dengan cara pengamatan dengan secara langsung terhadap objek penelitian. Observasi merupakan salah satu teknik pengumpulan data yang cukup efektif untuk mempelajari sistem yang ada. Dalam hal ini Peneliti melakukan observasi ke Apotek Global Martubung Medan.

b. Wawancara

Teknik wawancara ini dilakukan untuk mendapatkan informasi tambahan dari pihak-pihak yang memiliki wewenang dan berinteraksi langsung dengan sistem yang akan dirancang sebagai sumber data. Dalam hal ini peneliti melakukan wawancara secara langsung dengan pemilik Apotek Global Martubung Medan.

\begin{tabular}{|c|c|l|}
\hline No & Nama Supplier & \multicolumn{1}{|c|}{ Alamat/Lokasi } \\
\hline 1 & Surya Wahana & Jln.Ngumban Surbakti No.19 Blok B Medan \\
\hline 2 & $\begin{array}{c}\text { PT.Metro Artha } \\
\text { Prakarsa }\end{array}$ & Jln.Mesjid Taufiq No.120 B/C Medan \\
\hline 3 & PT.Mestika Sakti & Jln.Veteran No.64-70 Medan \\
\hline 4 & Apotek Airmas & Jln.Ngumban Surbakti No.16 A Medan \\
\hline 5 & CV.Megah Excellent & $\begin{array}{l}\text { Jln.Jamin Ginting KM 10,5 No 4 Medan } \\
\text { Selayang }\end{array}$ \\
\hline 6 & PT. Sumber Giat Utama & Jln Tumapel No.3-A Medan \\
\hline 7 & PT. SRB/ABA/MCJ & Jln Sumbawa No.8 KM 11, Mabar Medan \\
\hline 8 & PT.Garuda Perkasa & Jln. Cemara Asri No 110 Medan \\
\hline 9 & PT.Nusantara Jaya & Jln. Cemara Asri No 10 Block C Deli Serdang \\
\hline
\end{tabular}




\section{PT.Antarmitra Sembada Jln.Sei Batang Hari No. 53/57 Kel Sei Kambing}

\section{Gambar 1 Representasi Linear Naik}

\section{Study of Literature (Studi Kepustakaan)}

Dalam penelitian ini, peneliti melakukan studi kepustakaan yang bersumber dari berbagai buku referensi diantaranya adalah Jurnal (internasional, nasional dan lokal) ,buku-buku, artikel, situs dan lain-lain. Adapun referensi tersebut terkait dengan masalah bidang Keilmuan, Metode yang digunakan serta aplikasi pendukung lainnya. Dari komposisi yang ada jumlah Literatur yang digunakan sebanyak 24. Diharapkan dengan literatur tersebut dapat membantu peneliti didalam menyelesaikan permasalahan yang terjadi pada Apotek Global Martubung Medan.

Dikarenakan dalam penelitian ini menggunakan konsep pendekatan eksperimental maka dibawah ini adalah metode penelitian yaitu sebagai berikut :

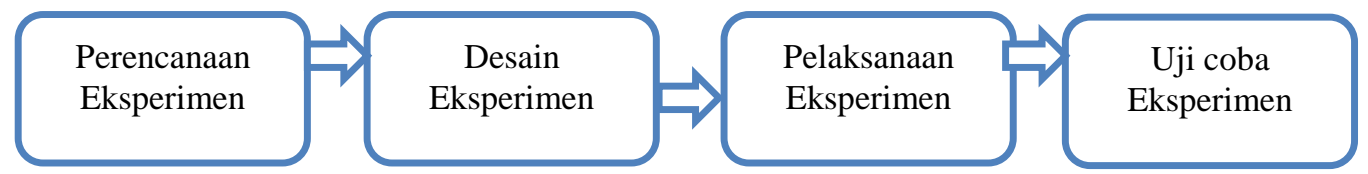

\section{Gambar 2.1 Metode Penelitian yang dilakukan}

Gambar diatas menjelaskan bahwa bagaimana cara melakukan penelitian, hal pertama yang dilakukan dalam penelitian yaitu melakukan perencanaan eksperimen dimana dalam hal peneliti merancang eksperimen apa yang akan dilakukan dengan terjun langsung ke Apotek Global Martubung Medan, tahap kedua peneliti mendesain eksperimen yang sudah diteliti terlebih dahulu ,tahap ketiga peneliti melakukan eksperimen Apotek Global Matubung dengan mengambil data yang diperlukan untuk diterapkan kedalam sistem dan tahap yang terakhir yaitu melakukan uji coba dalam sistem .

\section{ANALISA DAN HASIL}

\subsection{Algoritma Sistem}

Algoritma sistem merupakan penjelasan langkah-langkah penyelesaian masalah dalam perancanngan sistem pendukung keputusan dalam memilih supplier terbaik dengan menggunakan metode fuzzy tsukamoto. Hal ini digunakan untuk meningkatkan produktifitas dan keberhasilan perusahaan dalam menghadapi persaingan dunia bisnis khususnya di dunia teknologi. berikut

Algoritma pada metode Fuzzy Tsukamoto dengan menjalankan lima proses sebagai

1. Menentukan Kriteria

2. Fuzzyfikasi

3. Pembentukan Basis Pengetahuan (rule dalam if...then Nilai Fuzzy)

Kumpulan rule-rule fuzzy yang digunakan dalam bentuk pernyataan IF...THEN

4. Mesin Inferensi (fungsi implikasi max-min)

Proses untuk mengubah masukan fuzzymenjadi keluaran fuzzy dengan cara mengikuti aturan-aturan (if...then NilaiFuzzy rules)

5. Defuzzyfikasi :Mengubah keluaran fuzzy yang diperoleh dari mesin inferensi menjadi nilai tegas (rata-rata) menggunakan fungsi keanggotaan.

a. Dekripsi Data Dari Penelitian

Berikut ini adalah data yang digunakan sebagai sampel dalam penelitian ini adalah sebagai berikut:

\subsection{Menentukan Kriteria Penilaian}

Dalam merancang sistem pendukung keputusan menentukan supllier obat terbaik diperlukan beberapa kriteria-kriteria. Adapun kriteia yang telah ditetapkan oleh perusahaan dalam hal menentukan supplier obat terbaik yaitu: 
Tabel 3.1 Kriteria Penilaian

\begin{tabular}{|c|c|c|}
\hline No & Kode & Kriteria penilaian \\
\hline 1 & K1 & Pelayanan \\
\hline 2 & K2 & Diskon \\
\hline 3 & K3 & Fleksibilitas \\
\hline 4 & K4 & Waktu pengiriman \\
\hline
\end{tabular}

3.3 Menentukan Alternatif Kasus

Alternatif supplier obat yang digunakan sebagai penilaian sampel kasus ada 10, seperti yang tercantum pada tabel 3.2 dibawah ini

Tabel 3.2 Nilai Alternatif Suplier

\begin{tabular}{|c|c|c|c|}
\hline No & $\begin{array}{l}\text { Kode } \\
\text { Supplier }\end{array}$ & Nama Supplier & Keterangan \\
\hline 1 & S-01 & PT.Surya Wahana & $\begin{array}{lc}\text { Pelayanan } & : 80 \\
\text { Diskon } & : 60 \\
\text { Fleksibilitas } & : 65 \\
\text { Waktu Pengiriman }: 60\end{array}$ \\
\hline 2 & S-02 & PT.Metro Artha Perkasa & $\begin{array}{lc}\text { Pelayanan } & : 70 \\
\text { Diskon } & : 75 \\
\text { Fleksibilitas } & : 70 \\
\text { Waktu Pengiriman } & : 80\end{array}$ \\
\hline 3 & S-03 & PT.Mestika Sakti & $\begin{array}{lc}\text { Pelayanan } & : 75 \\
\text { Diskon } & : 65 \\
\text { Fleksibilitas } & : 65 \\
\text { Waktu Pengiriman } & : 80\end{array}$ \\
\hline 4 & S-04 & Apotek Airmas & $\begin{array}{lc}\text { Pelayanan } & : 80 \\
\text { Diskon } & : 65 \\
\text { Fleksibilitas } & : 60 \\
\text { Waktu Pengiriman } & : 70\end{array}$ \\
\hline 5 & S-05 & CV.Megah Excellent & $\begin{array}{lc}\text { Pelayanan } & : 80 \\
\text { Diskon } & : 65 \\
\text { Fleksibilitas } & : 60 \\
\text { Waktu Pengiriman } & : 80\end{array}$ \\
\hline 6 & S-06 & PT. Sumber Giat Utama & $\begin{array}{lc}\text { Pelayanan } & : 70 \\
\text { Diskon } & : 65 \\
\text { Fleksibilitas } & : 75 \\
\text { Waktu Pengiriman } & : 80\end{array}$ \\
\hline 7 & S-07 & PT. SRB/ABA/MCJ & $\begin{array}{lc}\text { Pelayanan } & : 80 \\
\text { Diskon } & : 60 \\
\text { Fleksibilitas } & : 60 \\
\text { Waktu Pengiriman } & : 70\end{array}$ \\
\hline 8 & S-08 & PT.Garuda Perkasa & $\begin{array}{lr}\text { Pelayanan } & : 80 \\
\text { Diskon } & : 60 \\
\text { Fleksibilitas } & : 60 \\
\text { Waktu Pengiriman } & : 80\end{array}$ \\
\hline
\end{tabular}




\begin{tabular}{|c|c|c|lc|}
\hline 9 & & & Pelayanan & $: 80$ \\
& & & Diskon & $: 60$ \\
& & & Fleksibilitas $: 65$ \\
& S-09 & PT.Nusantara Jaya & Waktu Pengiriman :70 \\
\hline 10 & & & Pelayanan & $: 70$ \\
& & & Diskon & $: 75$ \\
& & Fleksibilitas $: 70$ \\
& S-10 & PT.Antarmitra Sembada & Waktu Pengiriman :80 \\
\hline
\end{tabular}

\subsection{Mengisi Nilai Kriteria Pada Tiap Supplier Alternatif Obat}

Setelah data sudah ditentukan, lalu mengisi nilai tiap kriteria pada tiap-tiap alternatif supplier obat. Nilai kriteria akan dibuat untuk masing-masing alternatif guna memudahkan dalam penginputan nilainya,seperti dibawah ini.

Tabel 3.3 Nilai kriteria

\begin{tabular}{|l|c|l|l|l|l|}
\hline No & \multirow{2}{*}{$\begin{array}{c}\text { Kode } \\
\text { supplier }\end{array}$} & \multicolumn{4}{|c|}{ Nilai Kriteria } \\
\cline { 3 - 6 } & & $\begin{array}{c}\text { K1 } \\
\text { (Pelayanan) }\end{array}$ & $\begin{array}{c}\text { K2 } \\
\text { (Diskon) }\end{array}$ & $\begin{array}{c}\text { K3 } \\
\text { (Fleksibilitas) }\end{array}$ & $\begin{array}{c}\text { K4 } \\
\text { (Pengiriman) }\end{array}$ \\
\hline 1 & S-01 & Sangat Baik & Kecil & Tidak Terpenuhi & Lama \\
\hline 2 & S-02 & Sangat Baik & Besar & Terpenuhi & Cepat \\
\hline 3 & S-03 & Baik & Kecil & Terpenuhi & Lama \\
\hline 4 & S-04 & Sangat Baik & Kecil & Terpenuhi & Cepat \\
\hline 5 & S-05 & Sangat Baik & Kecil & Terpenuhi & Cepat \\
\hline 6 & S-06 & Baik & Kecil & Terpenuhi & Cepat \\
\hline 7 & S-07 & Sangat Baik & Kecil & Terpenuhi & Cepat \\
\hline 8 & S-08 & Sangat Baik & Kecil & Terpenuhi & Cepat \\
\hline 9 & S-09 & Sangat Baik & Kecil & Terpenuhi & Cepat \\
\hline 10 & S-10 & Baik & Besar & Terpenuhi & Cepat \\
\hline
\end{tabular}

Ket : Nilai di dapatkan dari bobot kriteria Fuzzy

Contoh : S-01 Pelayanan = sangat baik, maka nilai bobot fuzzy $=80$

Diskon = kecil , maka nilai bobot fuzzy $=60$

Fleksibilitas $=$ Tidak Terpenuhi, maka nilai bobot fuzzy $=65$

Pengiriman $=$ Lama , maka nilai bobot fuzzy $=60$

\subsection{Pengujian Validitas Rule}

Basis pengetahuan atau aturan yang digunakan dalam sistem pendukung keputusan yang dirancangkan berupa aturan if...then Nilai Fuzzy maka terbentuk aturan-aturan yang berjumlah 16 rule pada tabel dibawah ini.

Tabel 3.4 Pengujian Validitas Rule

\begin{tabular}{|c|c|c|c|c|}
\hline Rule & K1 & K2 & K3 & K4 \\
\hline 01 & Baik & Kecil & Tidak Terpenuhi & Lama \\
\hline 02 & Baik & Kecil & Tidak Terpenuhi & Cepat \\
\hline 03 & Sangat Baik & Kecil & Tidak Terpenuhi & Lama \\
\hline 04 & Baik & Besar & Tidak Terpenuhi & Lama \\
\hline 05 & Baik & Kecil & Terpenuhi & Lama \\
\hline 06 & Baik & Kecil & Terpenuhi & Cepat \\
\hline 07 & Sangat Baik & Besar & Tidak Terpenuhi & Lama \\
\hline 08 & Sangat Baik & Besar & Terpenuhi & Lama \\
\hline 09 & Baik & Besar & Terpenuhi & Cepat \\
\hline 10 & Sangat Baik & Besar & Tidak Terpenuhi & Cepat \\
\hline 11 & Sangat Baik & Kecil & Terpenuhi & Cepat \\
\hline 12 & Baik & Besar & Tidak Terpenuhi & Cepat \\
\hline 13 & Sangat Baik & Kecil & Terpenuhi & Lama \\
\hline
\end{tabular}




\begin{tabular}{|c|c|c|c|c|}
\hline 14 & Sangat Baik & Kecil & Tidak Terpenuhi & Cepat \\
\hline 15 & Baik & Besar & Terpenuhi & Lama \\
\hline 16 & Sangat Baik & Besar & Terpenuhi & Cepat \\
\hline
\end{tabular}

Kriteria dan nilai bobot yang digunakan dalam proses penyeleksian sebagai berikut:

Tabel 3.5 Nilai minimum dan maksimum kriteria

\begin{tabular}{|c|c|c|c|}
\hline No & Nilai kriteria & Interval & Keterangan \\
\hline 1 & $0<\mathrm{x}<=50$ & Minimum & Rendah \\
\hline 2 & $51<\mathrm{x}<=100$ & Maximum & Tinggi \\
\hline
\end{tabular}

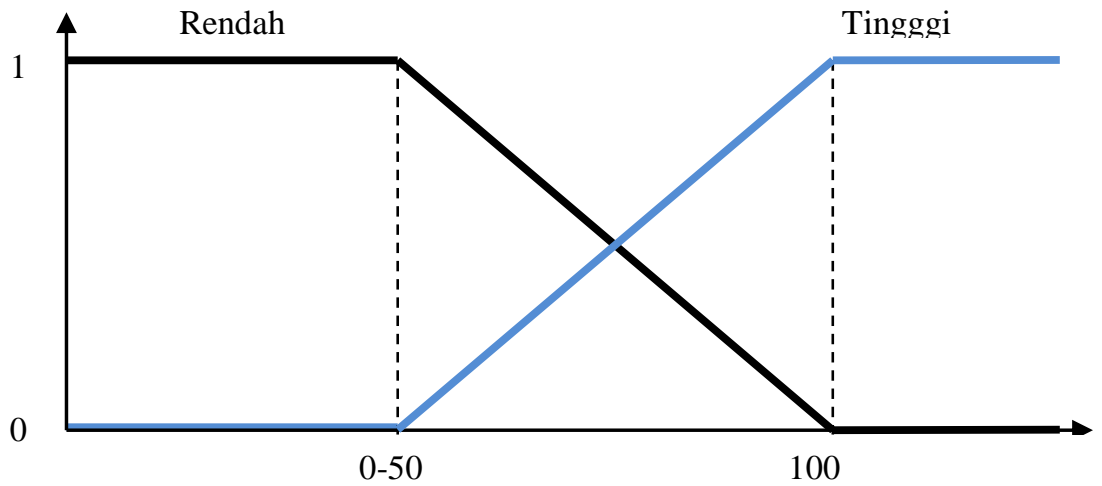

Gambar 3.1 Kurva Bobot Interval Kriteria

\subsection{Proses Fuzzyfikasi}

1. Surya Wahana (S-01)

Data supplier S-01 untuk diperhitungkan nilai kelayakannya dengan menggunakan metode Fuzzyfikasi dengan ketentuan data sebagai berikut:

1. Maka nilai Fuzzyfikasi untuk kriteria Pelayanan (80) pada Supplier S-01:

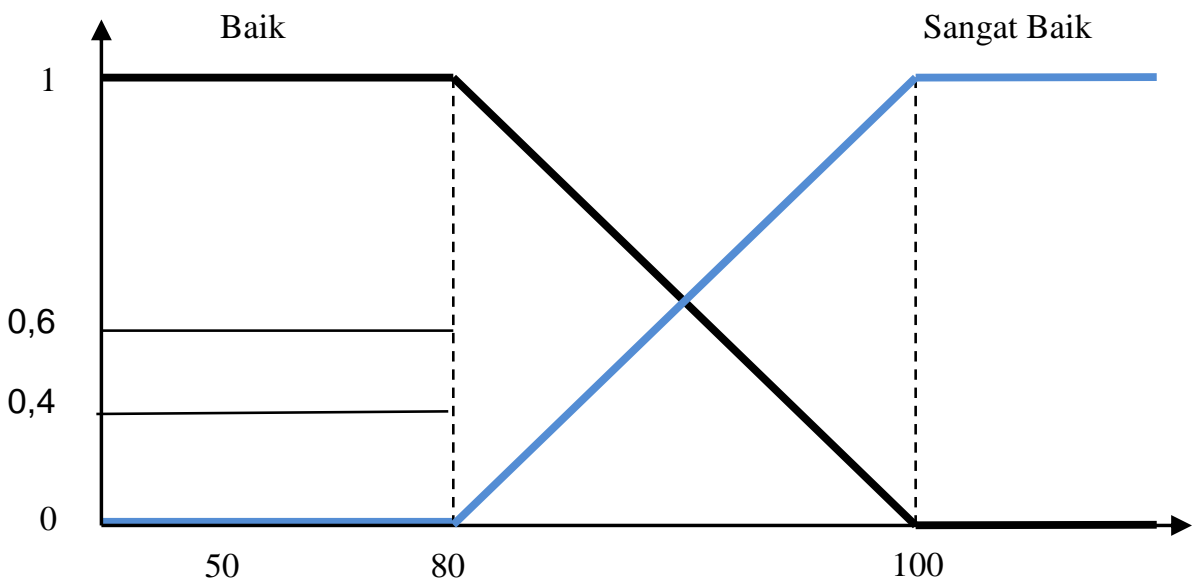

Gambar 3.2 Kurva Pelayananan

$\mu$ Sangat Baik $(80)=\frac{\max -x}{\max -\min }=\frac{100-80}{100-50}=\frac{20}{50}=0,4$

$\mu$ Baik $\quad(80)=\frac{x-\min }{\max -\min }=\frac{80-50}{100-50}=\frac{30}{50}=0,6$

2. Maka nilai Fuzzyfikasi untuk kriteria Diskon (60) pada Supplier S-01:

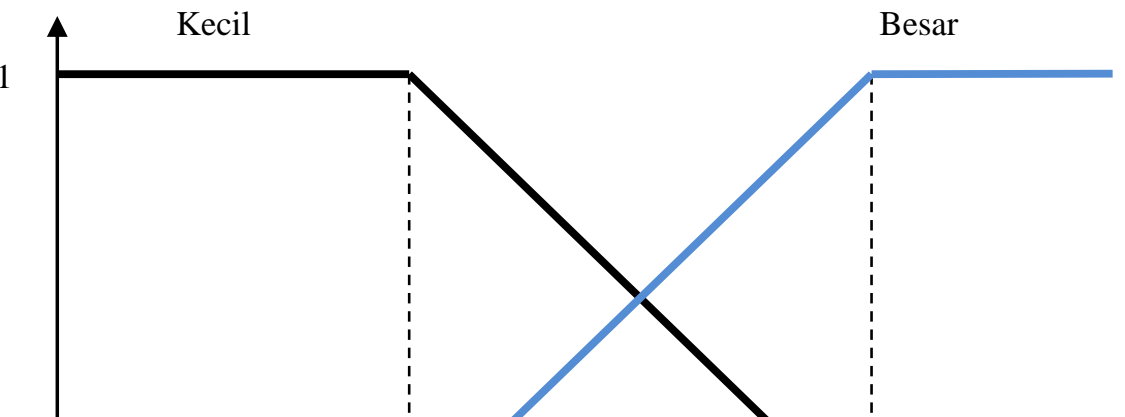


0,8

0,2

\section{Gambar 3.3 Kurva Diskon}

$\mu$ Besar $(60)=\frac{\max -x}{\max -\min }=\frac{100-60}{100-50}=\frac{40}{50}=0,8$

$\mu$ Kecil $(60)=\frac{x-\min }{\max -\min }=\frac{60-50}{100-50}=\frac{10}{50}=0,2$

3. Maka nilai Fuzzyfikasi untuk kriteria Fleksibilitas (65) pada Supplier S-01:

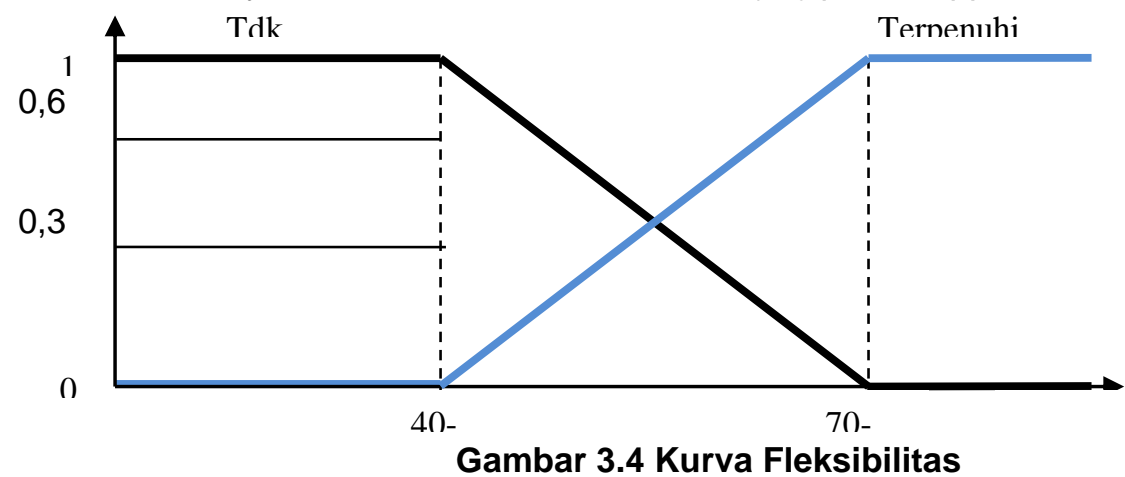

$\mu$ Terpenuhi (65) $=\frac{\max -x}{\max -\min }=\frac{100-65}{100-50}=\frac{35}{50}=0,7$

$\mu$ Tidak Terpenuhi $(65)=\frac{x-\min }{\max -\min }=\frac{65-50}{100-50}=\frac{15}{50}=0,3$

4. Maka Fuzzyfikasi untuk kriteria Waktu Pengiriman (60) pada Supplier S-01:

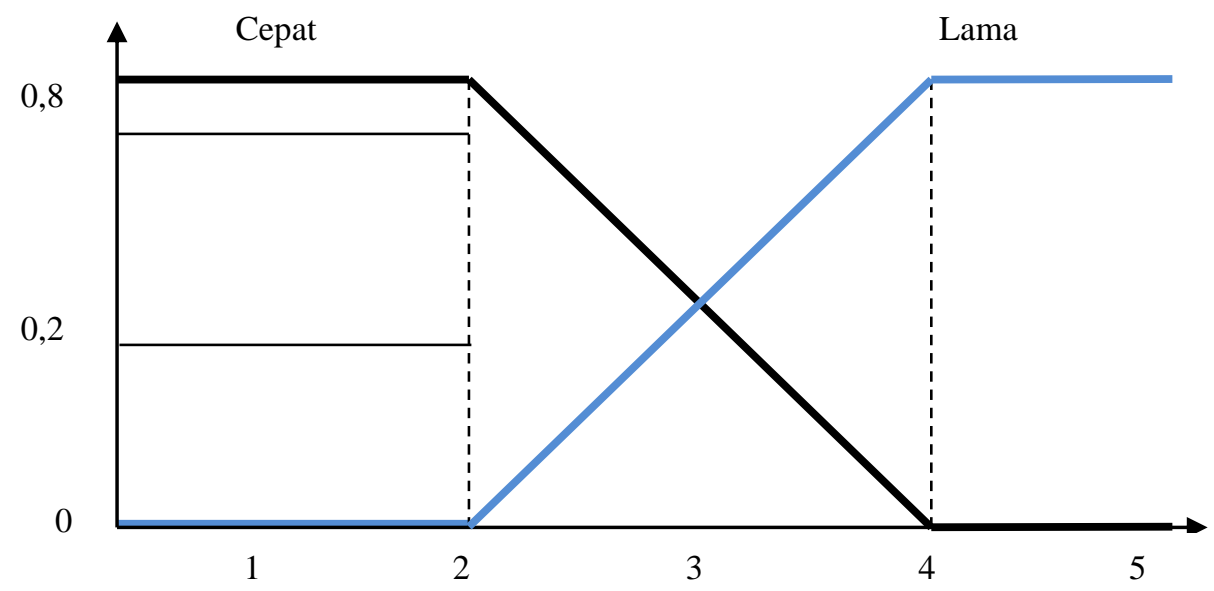

Gambar 3.5 Fungsi Keanggotaan Waktu Pengiriman

$\mu$ Cepat $(60)=\frac{\max -x}{\max -\min }=\frac{100-60}{100-50}=\frac{40}{50}=0,8$

$\mu$ Lama $(60)=\frac{x-\min }{\max -\min }=\frac{60-50}{100-50}=\frac{10}{50}=0,2$

3.7Proses Mesin Inferensi 
Langkah selanjutnya adalah melakukan inferensi rule. Pada fungsi inferensi harus mengetahui rule, yang digunakan pada sistem untuk mendapatkan nilai yang akan yang akan digunakan pada proses dezufizzykasi. Berikut penjelasan proses inferensi dibawah ini.

Rule 1: if K1 Baik and K2 Kecil and K3 Tidak Terpenuhi and K4 Lama Then Fuzzyfikasi (z)

(R1) $\alpha$-predikat1 $=\mu$ BaikoKeciloTidak TerpenuhioLama

$=\min (\circ B a i k(80) \curvearrowright \mu K e c i l(60) \curvearrowright \mu$ Tidak Terpenuhi(65) $\mu$ Lama(60)

$=\min (0,6,0,2,0,3,0,2)$

z1

a- predikat $1=0,2$

$=$ zMax- $\alpha$-predikat $1{ }^{*}(z \operatorname{Max}-z \operatorname{Min})$

$=100-0,2^{*}(100-50)$

$=100-(0,2 * 50)$

$=100-10$

$\mathrm{z1} \quad=90$

Rule 2: if K1 Baik and K2 Kecil and K3 Tidak Terpenuhi and K4 Cepat Then Fuzzyfikasi (z)

(R2) $\alpha$-predikat1 $=\mu$ BaikoKecilroTidak TerpenuhioCepat

$=\min (\circ B a i k(80) \curvearrowright \mu K e c i l(60) \circ \mu$ Tidak Terpenuhi(65) $\lrcorner \mu$ Cepat $(60)$

$=\min (0,6,0,2,0,3,0,2)$

z2

$\alpha$ - predikat $1=0,2$

$=$ zMax- $\alpha$-predikat $1 *$ (zMax-zMin $)$

$=100-0,2^{*}(100-50)$

$=100-(0,2 * 50)$

$=100-10$

$\mathrm{z2} \quad=90$

Rule 3: if K1 Sangat Baik and K2 Kecil and K3 Tidak Terpenuhi and K4 Lama Then Fuzzyfikasi (z)

(R3) $\alpha$-predikat1 $=\mu$ BaikoKeciloTerpenuhioLama

$=\min (\curvearrowright B a i k(80) \curvearrowright \mu K e c i l(60) \circ \mu$ Terpenuhi(65) $\mu$ Lama(60)

$=\min (0,6,0,2,0,7,0,2)$

z3 =zMax- $\alpha$-predikat $1 *(z \operatorname{Max}-z \operatorname{Min})$

$=100-0,2^{*}(100-50)$

$=100-(0,2 * 50)$

$\mathrm{z3} \quad=90$

Rule 4: if K1 Baik and K2 Besar and K3 Tidak Terpenuhi and K4 Lama Then Fuzzyfikasi ( $\mathrm{z}$ )

(R4) $\alpha$-predikat $1=\mu$ BaikoBesarroTidak TerpenuhioLama

$=\min (\curvearrowright$ Baik $(80) \curvearrowright \mu B e s a r(60) \curvearrowright \mu$ Tidak Terpenuhi(65) $\mu$ Lama(60)

$=\min (0,6,0,8,0,3,0,2)$

$\alpha$ - predikat $1=0,2$

z4 =zMax- $\alpha$-predikat $1 *(z M a x-z M i n)$

$=100-0,2^{*}(100-50)$

$=100-\left(0,2^{\star} 50\right)$

$=100-10$

z4 $=90$

Rule 5: if K1 Baik and K2 Kecil and K3 Terpenuhi and K4 Lama Then Fuzzyfikasi (z)

(R5) $\alpha$-predikat $1=\mu$ BaikoKeciloTerpenuhioLama

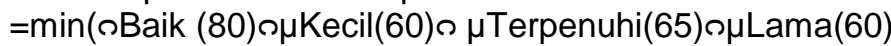

$=\min (0,6,0,2,0,7,0,2)$

z5 $=$ zMax- $\alpha$-predikat $1 *(z M a x-z M i n)$

$=100-0,2^{*}(100-50)$

$=100-(0,2 * 50)$

$=100-10$

z5 $=90$

Rule 6: if K1 Baik and K2 Kecil and K3 Terpenuhi and K4 Cepat Then Fuzzyfikasi (z)

(R6) $\alpha$-predikat1 $=\mu$ BaikoKeciloTerpenuhioLama

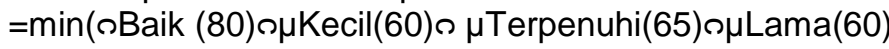




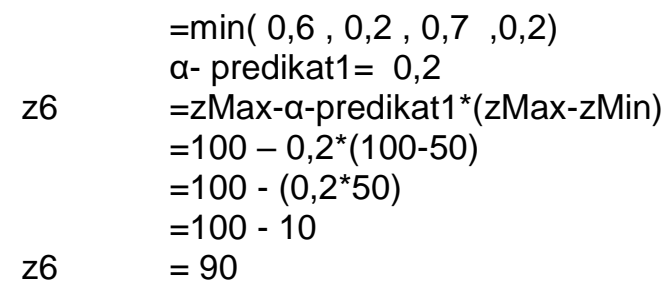

Rule 7: if K1 Sangat Baik and K2 Besar and K3 Tidak Terpenuhi and K4 Lama Then Fuzzyfikasi (z)

(R7) $\alpha$-predikat1 $=\mu$ Sangat BaiknBesaroTidak TerpenuhioLama

$=\min (\circ$ SangatBaik $(80) \curvearrowright \mu \operatorname{Besar}(60) \curvearrowright \mu$ Tidak Terpenuhi(65) $\lrcorner \mu \operatorname{Lama}(60)$

$=\min (0,4,0,8,0,3,0,2)$

z7 $\quad=z$ Max- $\alpha$-predikat $1 *(z M a x-z M i n)$

$=100-0,2^{*}(100-50)$

$=100-(0,2 * 50)$

$=100-10$

z7 $\quad=90$

Rule 8: if K1 Sangat Baik and K2 Besar and K3 Terpenuhi and K4 Lama Then Fuzzyfikasi (z)

(R8) $\alpha$-predik1= $\mu$ Sangat BaiknBesaroTerpenuhioLama

$=\min (\circ$ SangatBaik $(80) \curvearrowright \mu B e s a r(60) \curvearrowright \mu$ Terpenuhi(65) $\mu \mu \operatorname{Lama}(60)$

$=\min (0,4,0,8,0,7,0,2)$

$z 8$

$\alpha$ - predikat $1=0,2$

$=$ zMax- $\alpha$-predikat $1 *$ (zMax-zMin)

$=100-0,2^{*}(100-50)$

$=100-\left(0,2^{*} 50\right)$

z8 $\quad=90$

$=100-10$

Rule 9: if K1 Baik and K2 Besar and K3 Terpenuhi and K4 Cepat Then Fuzzyfikasi (z)

(R9) $\alpha$-predikat1 $=\mu$ BaikoBesaroTerpenuhisCepat

$=\min (\curvearrowright B a i k(80) \curvearrowright \mu B e s a r(60) \curvearrowright \mu$ Terpenuhi $(65) \curvearrowright \mu$ Cepat $(60)$

$=\min (0,6,0,8,0,7,0,8)$

$\alpha$ - predikat $1=0,6$

z9 $=$ zMax- $\alpha$-predikat ${ }^{*}(\mathrm{zMax}-\mathrm{zMin})$

$=100-0,6^{*}(100-50)$

$=100-\left(0,6^{\star} 50\right)$

$=100-30$

$\mathrm{z9} \quad=70$

Rule 10: if K1 Sangat Baik and K2 Besar and K3 Tidak Terpenuhi and K4 Cepat Then Fuzzyfikasi (z)

(R10) $\alpha$-predikat $1=\mu$ Sangat BaikoBesaroTidak TerpenuhisCepat

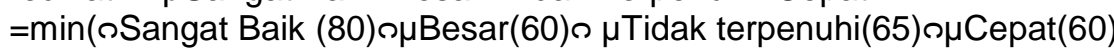

$=\min (0,4,0,8,0,3,0,8)$

$\alpha$ - predikat $1=0,3$

z10 =zMax- $\alpha$-predikat $1 *(z M a x-z M i n)$

$=100-0,3^{*}(100-50)$

$=100-\left(0,3^{*} 50\right)$

$=100-15$

$\mathrm{z} 10=85$

Rule 11: if K1 Sangat Baik and K2 Kecil and K3 Terpenuhi and K4 Cepat Then Fuzzyfikasi ( $\mathrm{z}$ )

(R11) $\alpha$-predikat $1=\mu$ Sangat BaikokeciloTerpenuhioCepat

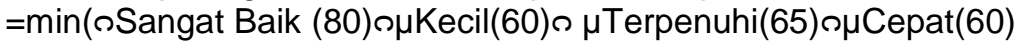

$=\min (0,4,0,3,0,7,0,8)$

$\alpha$ - predikat $1=0,2$

z11 =zMax- $\alpha$-predikat ${ }^{*}(z \operatorname{Max}-z \operatorname{Min})$

$=100-0,2^{*}(100-50)$

$=100-\left(0,2^{*} 50\right)$ 
$\begin{aligned} & =100-10 \\ z 11 & =90\end{aligned}$

Rule 12: if K1 Baik and K2 Besar and K3 Tidak Terpenuhi and K4 Cepat Then Fuzzyfikasi (z)

(R12) $\alpha$-predikat1 $=\mu$ BaikøBesaroTidak Terpenuhiocepat

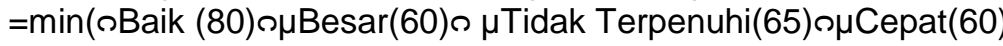

$=\min (0,6,0,8,0,7,0,8)$

$\alpha$ - predikat $1=0,6$

z12 =zMax- $\alpha$-predikat1* $(z M a x-z M i n)$

$=100-0,6^{*}(100-50)$

$=100-(0,6 * 50)$

$=100-30$

$\mathrm{z} 12=70$

Rule 13: if K1 Sangat Baik and K2 Kecil and K3 Terpenuhi and K4 Lama Then Fuzzyfikasi (z)

(R13) a-predikat1 = $\mu$ Sangat BaikoKecilroTerpenuhioLama

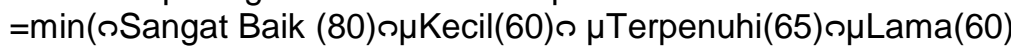

$=\min (0,4,0,2,0,7,0,2)$

$\alpha$ - predikat $1=0,2$

z13 =zMax- $\alpha-$ predikat $1 *(z M a x-z M i n)$

$=100-0,2^{*}(100-50)$

$=100-(0,2 * 50)$

$=100-10$

$z 13=90$

Rule 14: if K1 Sangat Baik and K2 Kecil and K3 Terpenuhi and K4 Lama Then Fuzzyfikasi (z)

(R14) a-predikat1= $\mu$ SangatBaikoKeciloTerpenuhioLama

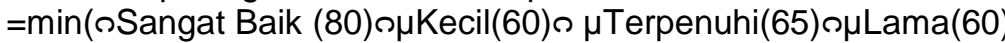

$=\min (0,4,0,2,0,7,0,8)$

$\alpha$ - predikat $1=0,2$

z14 =zMax- $\alpha$-predikat $1 *$ (zMax-zMin)

$=100-0,2^{*}(100-50)$

$\mathrm{z} 14=100-(0,2 * 50)$

$=100-10$

$\mathrm{z} 14=90$

\subsection{Proses Defuzzyfikasi}

Untuk proses defuzzyfikasi pada sistem pendukung keputusan penentuan supplier pembelian obat terbaik dihitung dengan menjumlahkan hasil perkalian $\alpha$-predikat dengan nilai $z$ dan di bagi dengan jumlah $\alpha$-predikat atau seperti rumus berikut untuk sampel data alternatif supplier:

Defuzzyfikasi Surya Wahana (S-01) :

$$
z=\frac{\left(\text { opredikat }_{1} * z_{1}\right)+\left(\text { opredikat }_{2} * z_{2}\right)+\left(\text { opredikat }_{3} * z_{3}\right)+\text { opredikat }_{n} * z_{n}}{\text { opredikat }_{1}+\text { opredikat }_{2}+\text { opredikat }_{3}+\text { opredikat }_{n}}
$$

$=\frac{(0,2 * 90)+(0,2 * 90)+(0,2 * 90)+(0,2 * 90)+(0,2 * 90+(0,2 * 90)+(0,2 * 90)+(0,2 * 90)+(0,2 * 90) \ldots(a 16 * 16)}{0,2+0,2+0,2+0,2+0,2+0,2+0,2+0,2+0,6+0,3+0,2+0,6+02+0,2+0,2+0,4)}$ $0,2+0,2+0,2+0,2+0,2+0,2+0,2+0,2+0,6+0,3+0,2+0,6+02+0,2+0,2+0,4$

$z=\frac{375.5}{4.5}$

$z=83,44$

Berdasarkan perhitungan metode Fuzzy Tsukamoto diatas maka dapat disimpulkan perangkingan supplier S-01 sampai dengan S-10. Berikut adalah hasil perangkingan dari seluruh supplier:

Tabel 3.6 Hasil perangkingan Fuzzy

\begin{tabular}{|l|l|l|l|}
\hline Kode & Nama Supplier & Nilai Fuzzy & Keputusan \\
\hline S-01 & Surya Wahana & 83,44 & Terbaik \\
\hline S-02 & PT.Metro Artha Prakarsa & 67 & Sedang \\
\hline
\end{tabular}




\begin{tabular}{|l|l|l|l|}
\hline S-03 & PT.Mestika Sakti & 68 & Sedang \\
\hline S-04 & Apotek Airmas & 70,79 & Baik \\
\hline S-05 & CV.Megah Excellent & 72,73 & Baik \\
\hline S-06 & PT. Sumber Giat Utama & 76,07 & Baik \\
\hline S-07 & PT. SRB/ABA/MCJ & 71,21 & Baik \\
\hline S-08 & PT.Garuda Perkasa & 73,22 & Baik \\
\hline S-09 & PT.Nusantara Jaya & 72,83 & Baik \\
\hline S-10 & PT.Antarmitra Sembada & 67 & Sedang \\
\hline
\end{tabular}

Keterangan : Nilai $>=80$ ke atas adalah Terbaik

Nilai $>=70-79$ adalah Baik

Nilai $<=60-69$ adalah Sedang

Nilai $<=59$ ke bawah adalah Buruk

Maka dari perhitungan diatas dapat disimpulkan bahwa yang dinyatakan supplier terbaik pembelian obat adalah dengan nilai $>=80 \mathrm{ke}$ atas, sesuai dengan ketentuan dari Apotek Global Martubung. Sehingga Apotek Surya Wahana yang dinyatakan layak sebagai supplier terbaik seperti yang terlihat pada tabel diatas.

\section{KESIMPULAN}

Berdasarkan hasil analisa dari permasalahan yang terjadi dengan kasus yang di bahas tentang pemilihan supplier pembelian obat-obatan terbaik dengan menerapakan metode fuzzy tsukamoto pada Apotek Global Martubung terhadap sistem yang dirancang dan dibangun maka dapat ditarik kesimpulan sebagai berikut :

1. Untuk menganalisa permasalahan yang terjadi dalam pemilihan supplier obat yang terbaik yang ada pada Apotek Global Martubung dan menerapkan metode Fuzzy Tsukamoto

2. Untuk merancang aplikasi sistem pendukung yang menerapkan metode Fuzzy Tsukamoto yang dapat digunakan untuk melihat pola pembelian obat untuk mengetahui pemilihan supplier obat terbaik secara tepat dan akurat.

3. Untuk menerapkan aplikasi yang telah diuji pada Apotek Global Martubung sehingga dapat membantu pemilik didalam melihat informasi melalui pola pembelian supplier kepada Apotek Global Martubung

\section{REFERENSI}

[1] S. Informasi, "PROSIDING seminar nasional sisfotek Sistem Penunjang Keputusan Pemilihan Supplier pada Apotek dengan Metode AHP dan SAW ( Studi Kasus Apotek XYZ )," vol. 3584, pp. 107-114.

[2] T. Murti, L. A. Abdillah, and M. Sobri, "PINJAMAN DENGAN METODE FUZZY TSUKAMOTO,” pp. 252-256, 2015.

[3] A. Mulyanto and A. Haris, "Penerapan Metode Fuzzy Tsukamoto Untuk Menentukan Jumlah Jam Overtime Pada Produksi Barang di PT Asahi Best Base Indonesia ( ABBI ) Bekasi Abstrak," vol. 1, no. 1, pp. 1-11, 2016.

[4] M. Sholihin, N. Fuad, and N. Khamiliyah, "Sistem Pendukung Keputusan Penentuan Warga Penerima Jamkesmas Dengan Metode Fuzzy Tsukamoto," vol. 5, no. 2, pp. 501506, 2013. 